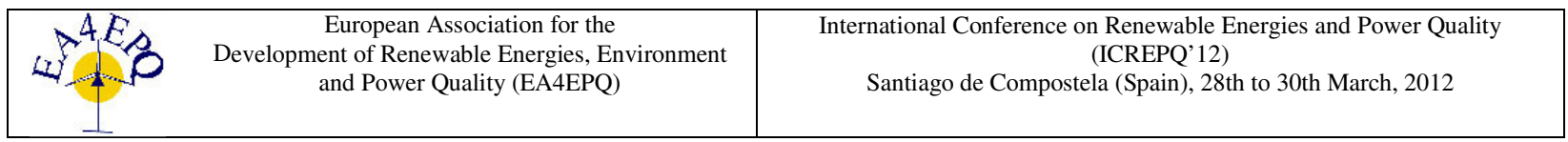

\title{
The Strategic Importance of the Electric Transmission in a System Based on Primary Renewable Source
}

\author{
T. H. V. Silveira ${ }^{1}$; A. A. Bertoni ${ }^{1}$, D. M. Silva ${ }^{1}$, L. C. Fonseca $^{1}$, A. F. V. Silveira ${ }^{1,3}$, \\ A. W. F. V. Silveira ${ }^{2}$ \\ ${ }^{1}$ Academic of Department of Electrical Engineering - PUC-Go, ${ }^{2}$ FEELT-UFU, ${ }^{3}$ UEG \\ Campus I, Area III - Setor Universitário, 74605-010 Goiânia (Brazil) \\ Phone number:+0055 3946 1351, e-mail: taina.hungria@gmail.com
}

\begin{abstract}
This article describes the characteristics of the Brazilian electric system, whose main generation source is hydroelectricity and how the country made stable and economic the supply of energy on a large scale, managing the uncertainties of this type of source. The study of how this country has been dealing with the variability of supply of each of their enterprises, using the storage capacity and deployment of the country's energy integration can be a source of inspiration for other countries on how to handle the various issues that arise in the integration between different energy sources.
\end{abstract}

\section{Key words}

Brazilian water basins; Hydroelectricity; Brazilian power system; Interconnected system.

\section{Introduction}

Electricity became one of the most versatile and convenient energy, becoming an indispensable resource and strategic for the socioeconomic development of many countries and regions [1].

The technological bases of engineering employed in the exploration, production and transportation of energy are dominated for over 100 years. The big development in this entire period is represented both by the power electronics and control electronics. Prospecting the great challenges of engineering applied to electrical systems, with building a bridge between two worlds is found. The first world is represented by the concentrated energy production and its transportation to the consumption centers. The other world is represented by energy production as close as possible to the consumption centers and consequently fairly distributed, making the consumer a potential energy producer.

The world of distributed power, even because of the growing and imperative attention to environmental sustainability is based on renewable energy as a primary source, usually subjected to supply variability by environmental and climatic characteristics only partially predictable and almost not controllable.

The construction of a bridge that integrates these two worlds represents the integration of the world of macro with the world of micro, randomly variable. This integration requires the compatibility and the development of knowledge and technologies to manage conflicts such as electrical voltage variations in different parts of the system and changes in level of short circuit, requiring increased use of transmission based on power electronics, as well as developments of methods and management of many energy sources [2].

Hydropower is a renewable source that currently represents the main source of energy for various countries. It accounts for about $17 \%$ of all electricity generated in the world [1]. In Brazil it counts for $75 \%$ at least of the national power production [3].

Although it is not a heavily distributed generation system, the study of how this country has been dealing with the variability of supply of each of their enterprises, using the storage capacity and deployment of the country's energy integration can be a source of inspiration for other countries on how to handle the various issues that arise in this integration between macro and micro worlds [2].

\section{Water Basins of Brazil}

Water basin is an area of land determined by topographic features, combined with a water surface and underground drainage forming a water table. The boundary of a water basin is established considering the topography, slope and watersheds [4].

Almost $13 \%$ of the world's surface water resources are in Brazil, with $182,633 \mathrm{~m}^{3} / \mathrm{s}$ flowing within the 8.57 million 
$\mathrm{km}^{2}$ of its land area. This natural endowment, while abundant in some regions, in others meets neither the demand from urban areas nor from industry in general. $73 \%$ of water resources are concentrated in the Amazon Water Basin, with only $4 \%$ of Brazil's population [5].

On the other hand, the Southeast Region, with $47 \%$ of the population, has only $8 \%$ of the country's water resources (Southeast Coast and Paraná Hydrographic Regions). The Eastern Northeast Coast Hydrographic Region, with 20\% of the Brazil's population, has only $2 \%$ of its water resources [6].

The water basins of Brazil are distributed as shown on the map below [7].

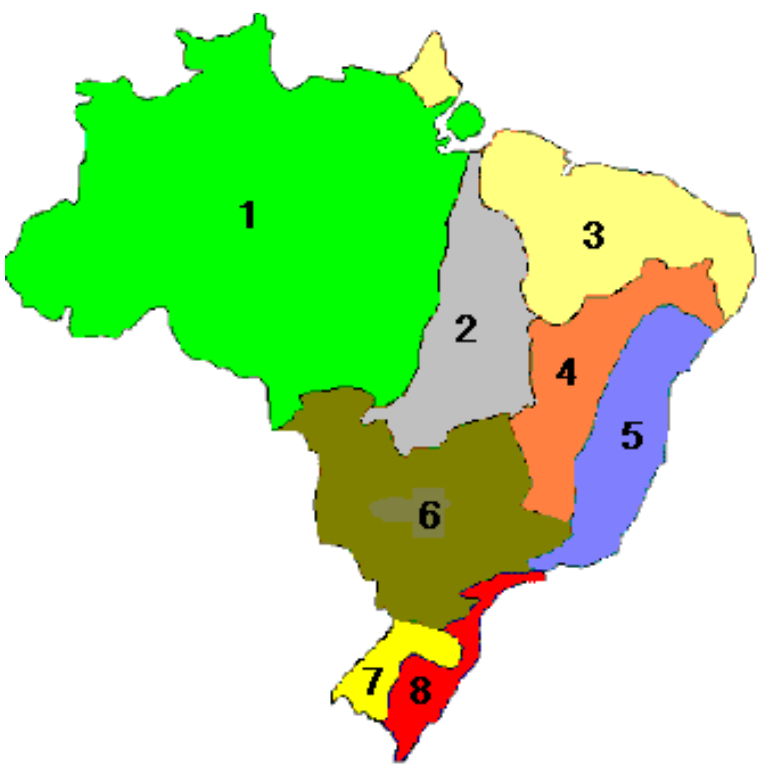

Fig. 1. Map of the Hydrographic Basins of Brazil Table I. The Hydrographic Basins of Brazil

\begin{tabular}{|l|r|r|}
\hline \multicolumn{3}{|c|}{ The Hydrographic Basins of Brazil } \\
\hline Basin & $\begin{array}{c}\text { Specific } \\
\text { flow } \\
\left(\mathbf{l} / \mathbf{s} / \mathbf{k m}^{2}\right)\end{array}$ & $\begin{array}{c}\text { Annual } \\
\text { Precipitation } \\
\text { (mm) }\end{array}$ \\
\hline Amazonas & 30.8 & 2,220 \\
Tocantins & 15.6 & 1,660 \\
Atlântico Norte & 48.2 & 2,950 \\
Atlântico Nordeste & 5.7 & 1,328 \\
São Francisco & 4.5 & 916 \\
Atlântico Leste & 14.9 & 2,124 \\
Paraná & 12.5 & 1,385 \\
Uruguai & 23.3 & 1,567 \\
Atlântico Sudeste & 19.2 & 1,394 \\
\hline
\end{tabular}

The development of hydroelectric studies, in other words, the further studies of the inventory stages, feasibility and basic design, identifies the economic, environmental and technical constraints, which often reduce the initially estimated hydropower potential [8].
Table II. Brazilian Hydroelectric Potencial per Basin (2010)

\begin{tabular}{|lr|}
\hline \multicolumn{2}{|c|}{ Brazilian Hydroeletric Potencial } \\
\hline \multicolumn{1}{|c|}{ Basin } & \multicolumn{1}{c|}{ MW } \\
\hline Amazonas & $89,897.61$ \\
Tocantins & $26,224.22$ \\
Atlântico Norte / Nordeste & $2,735.33$ \\
São Francisco & $26,051.43$ \\
Atlântico Leste & $13,990.46$ \\
Paraná & $62,301.69$ \\
Uruguai & $12,308.07$ \\
Atlântico Sudeste & $9,852.86$ \\
\hline
\end{tabular}

It is defined as Natural Affluent Energy, the sum of the controllable power, deriving from flow streaming to the reservoirs, with the energy of-river raw water flow coming to hydroelectric plants that do not admit reservoirs [9].

As shown on figures 03, 04, 05 and 06, the Natural Affluent Energy varies during the year depending on the country region [2].

As can be seen from the previous histograms, there is a diversity of natural hydrological cycles in each region and the economic utilization of the economic exploitation of natural inflowing energies requires energy to be transferred from regions that has low inflows to those with higher inflows.

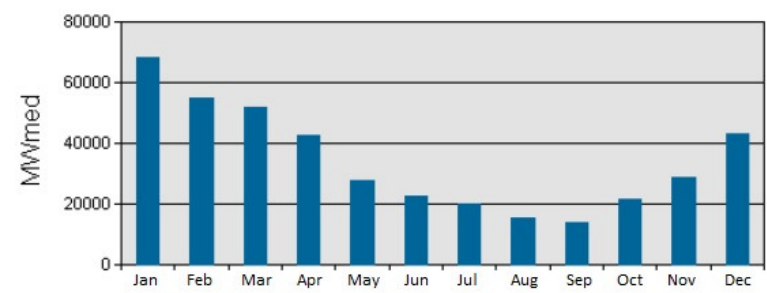

Fig. 2. Natural Affluent Energy on Southeast Region (2010)

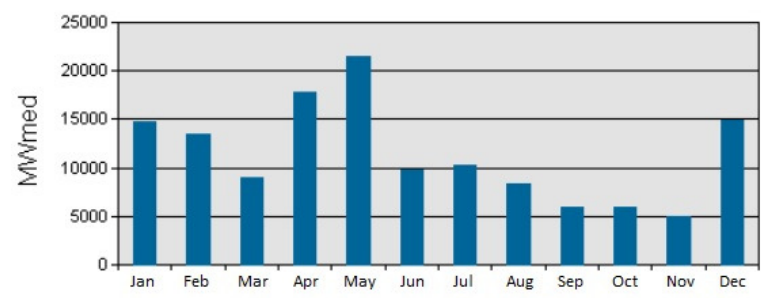

Fig. 3. Natural Affluent Energy on South Region (2010)

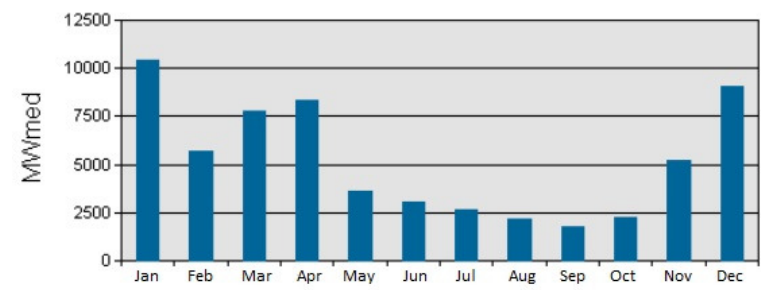

Fig. 4. Natural Affluent Energy on Northeast Region (2010) 


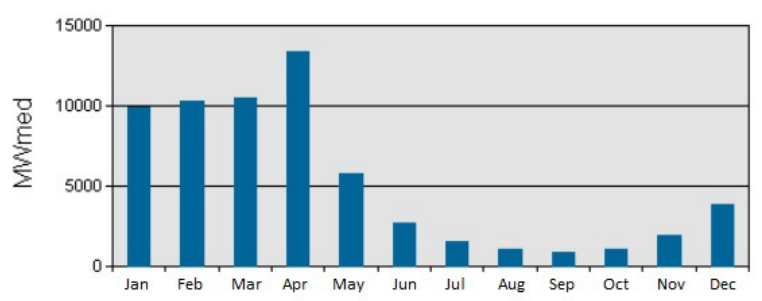

Fig. 5. Natural Affluent Energy on North Region (2010)

\section{Hydropower: The Main Energy Source of Brazil}

Hydraulic energy results of solar radiation and gravitational potential energy, which cause evaporation, condensation and precipitation of water on the surface. Unlike other renewable sources, represents a significant portion of global energy and has avail technology properly consolidated. It is currently the main source of energy for various countries and accounts for about $17 \%$ of all electricity generated in the world [1].

The domestic electricity supply in Brazil is historically based on hydraulic sources which today count for $88 \%$ of the national power production [3]. In recent years, with the increasing development of industrialization, the hydropower plants have been receiving support from both public and private area in Brazil. By producing clean, cheap and non-polluting energy, the sector has been growing at an accelerated rate [10].

Brazilian government has a fundamental role in the development of this area releasing loans and financing for construction and modernization of hydropower plants in the country through the National Bank of Economic and Social Development, an agency of the Ministry of Development, Industry and Foreign Trade [10].

Table III. Structure of Installed Capacity on National Interconnected System (2010)

\begin{tabular}{|lrr|}
\hline \multicolumn{1}{|c}{ Source } & \multicolumn{1}{c|}{ MW } & \multicolumn{1}{c|}{$\%$} \\
\hline Hydroelectric & 85.690 & $79,30 \%$ \\
Natural Gas & 9.308 & $8,60 \%$ \\
Conventional Thermoelectric & 5.626 & $5,20 \%$ \\
Nuclear & 2.007 & $1,90 \%$ \\
Wind / Biomass / Others & 5.403 & $5,00 \%$ \\
Total & 108.034 & $100,00 \%$ \\
\hline
\end{tabular}

The installed capacity of the National Interconnected System does not have the plants that have installed capacity less than $30 \mathrm{MW}[2]$.

The production of hydroelectric power can be attractive for the following reasons: air, water and soil pollution are reduced or zero; contributes to the goals of energy policy and sustainable development because it is a renewable energy source; a constructed dam may have other associated benefits such as public water supply, irrigation, creating a zone of leisure and tourism potential; electricity is cheaper for the consumer compared with other forms of energy such as wind, thermal or nuclear [10].

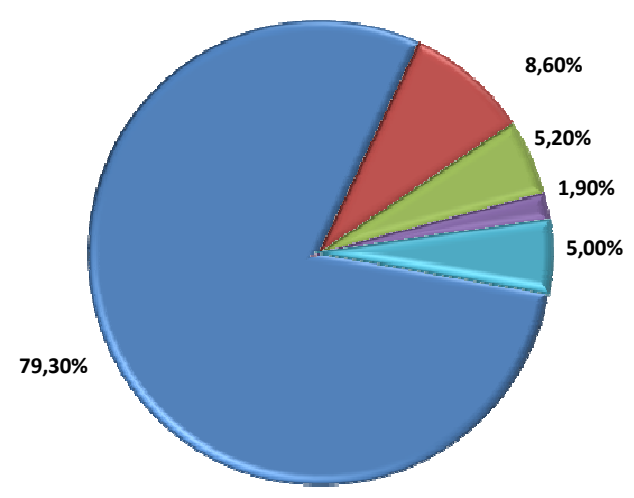

Fig. 6. Installed Capacity on National Interconnected System (2010)

In a system essentially hydraulic, the imposition of the coordination is much greater, including the power generation, is necessary to calculate, through the reservoirs, the firm energy, amount of energy that can be provided in the worst condition with a specified level of assurance. With a power plant operating isolated, the level may be insufficient, but with the the basin or a complete system operating in coordination, can lead to an increase in the level of hydroelectric power available for the same capacity and same level of investment [11].

The Brazilian hydroelectric plants have multiple owners, 35 public and private companies have 141 hydroelectric power plants with capacity above $30 \mathrm{MW}$ in 14 river basins, generating about $85.690 \mathrm{MW}$. Currently there are 69 plants with reservoir, 68 on trickle and 4 pumping plants. 18 new plants are under construction totaling 97,968 MW in the Integrated National System in 2015 [2].

The transmission system interconnecting river basins in Brazil was developed to enable a wide variety of settings dispatch, optimizing water resources in an integrated manner, enabling hydroelectric exploitations [12].

The transmission system has the effect of increasing the energetic availability of the set of plants since the excess of energy in a basin with no more storage capacity is transferred to plants with low inflow or with storage room. Thus the objective function of the energetic operation is the elimination of water loss with exploitations.

\section{National Interconnected System - SIN}

With size and characteristics that allow it to be considered unique worldwide, the system of production and transmission of electric energy in Brazil is a large hydrothermal system [1]. 
The first interconnected operation in Brazil took place in São Paulo in 1925 due to a serious problem in the supply of electricity, consequence of the sharp increase in energy consumption due to industrial development coupled with a severe drought in the state [13].

Currently, the National Interconnected System (SIN) covers 5 millin $\mathrm{Km}^{2}$, more than two thirds of national territory, the power consumption of the SIN in 2010 was 56,577 MWmed which corresponds to $98 \%$ of electricity consumption in the country. SIN consists of four subsystems: South, Southeast / Midwest, Northeast and North. Its installed capacity is composed mainly by hydroelectric plants distributed in twelve basins in different regions of the country [14].

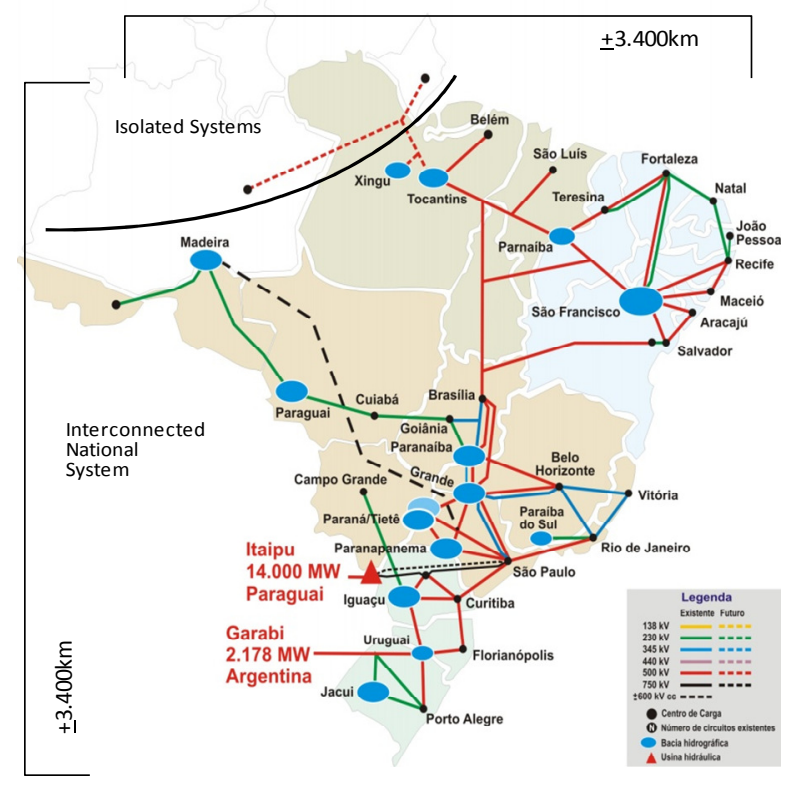

Fig. 7. Electrical Integration in Brazil (2010)

The fig. 7 shows the Brazilian transmission system, considering only the transmission lines with voltage greater than or equal to $230 \mathrm{KV}$, with more than 100 thousand $\mathrm{km}[2]$.

Table IV. Transmission Lines on National Interconnected System (2010).

\begin{tabular}{|lr|}
\hline \multicolumn{2}{|c|}{ Transmission Lines (2010) } \\
\hline Voltage [KV] & Extension [Km] \\
\hline 230 & $43.250,6$ \\
345 & $10.060,5$ \\
440 & $6.670,5$ \\
500 & $34.371,7$ \\
600 cc & $1.612,0$ \\
750 & $2.683,0$ \\
\hline SIN & $\mathbf{9 8 . 6 4 8 , 3}$ \\
\hline
\end{tabular}

These transmission lines interconnecting the various consumption centers and regions of the country. The access to this transmission system is opened to all members of the generation and distribution / commercialization markets [2].

The basic functions of the transmission system is to unite the plants installed in water falls to consumption centers and to provide the energy exchange between the reservoirs of the country [2].

Hydroelectric generation is predominant, about $79 \%$ of installed capacity and $88 \%$ of electricity production on 2010 , complemented by thermal generation with various sources such as nuclear, coal, natural gas, fuel oil and diesel, constituting about $16 \%$ of installed capacity. There is a small share, about $5 \%$ from other renewable sources like wind and biomass [2].

As dams are built in places where they can best take advantage of the influx of rivers and gaps, usually located in places far from consumers, it was necessary to develop an extensive transmission system in the country, 97,000 $\mathrm{km}$ of transmission lines above $230 \mathrm{kV}$ on 2010. This geographical distance, associated with the large territory and the climatic and hydrological variations of the Country, tend to cause excess or shortage of hydroelectric production in some regions on certain periods of the year [1].

It follows another major role in the transmission system that is the integration between the energetic regions of the country, allowing a reduction of production costs and investments in new plants, as shown bellow [2].

The interconnected system of electrification also allows different regions exchange energy with each other when one offers a drop in reservoir levels. As the rainfall is different in the South, Southeast, North and Northeast, large trunks, containing transmission lines of high power, $500 \mathrm{kV}$ or $750 \mathrm{kV}$, enable the points with insufficient production of energy to be supplied by generation at favorable situation [15].

The effective actions for the transfer of energy between subsystems contribute to improve the level of reservoirs, obeying the principle of fair distribution of burdens and benefits among all markets supplied by the SIN [13].

Among the advantages of interconnecting the system, it is possible to mention the effect of load diversity, proportional to the expansion of electrical system; optimization in the design and location of power plants, made possible through a coordinated planning; using a combination of cheaper units at any weather, to meet the demand of the interconnected system; and the best possible use of hydroelectric resources, through integrated operation of storage reservoirs and coordinated expansion of generating capacity [13].

The system is constantly evolving, which can alter the distribution of basins and plants, as well as their interconnections. The thermal power plants, often located near the load centers, play a strategic role contributing to SIN security. In periods of unfavorable hydrological 
conditions, the thermal plants are dispatched, allowing the storage of water in the reservoirs of hydroelectric plants to ensure future compliance [14].

\section{Operation of the Interconnected National System}

The operation of the system consists in programming, standardization, coordination, supervision, control, and statistical analysis of the integrated operation of the SIN, in order to ensure that it functions optimally, on a reliable and safe way, keeping its quality [14].

The coordination of the operation of the SIN is rooted in the operative interdependence between the power plants, the interconnection of electrical systems and the integration of generation and transmission resources. The National Electric System Operator - ONS, the independent system operator for all Brazilian territory, conducts technical coordination and control of the operation of generation and transmission of SIN's electricity. The other operators of the system are made up of generation and transmission agents that act directly on the operating network or on international interconnections; distribution agents, import agents, export agents; and consumers whose premises are connected to core network, being hierarchically subordinated to the ONS's National Center for Operations and Systems - CNOS [14].

The interdependence of the operating system results of joint use of hydroelectric resources, through the construction and operation of power plants and reservoirs located in cascade on several river basins. Thus, the operation of a particular plant depends not only on the upstream flow released by other plants, but also affects the downstream plants [14].

The hydraulic power plants belong to multiple owners, but the compensation of each plant is based on an average capacity of its delivery, calculated based on the river flows history. This way, the contracts have financial nature not being based on the physical quantities of energy delivery [2].

The real dispatch of each plant is determined by ONS, based on the energy optimization. The process of determining the dispatch values of the plants in each region considers flow forecasts for the next cycles, the initial flow rates of the reservoirs in the early periods of dispatch planning, as well as the capacity of internal thermoelectric production of each region and its import and export capabilities [2].

The interconnection of electrical systems through the transmission network, provides the energy transfer between subsystems, allows the obtainment synergistic gains with the optimal use of water resources and the optimal hydrothermal dispatch, exploring the diversity of hydrological basins. The integration of generation and transmission capabilities allows the service to market with security and economy [14].

The transmission systems belong to multiple owners, however, ONS controls the access, use and operation of the system, based on pre-established procedures approved by the regulatory agency [2].

Table IV. Power Exchanges on National Interconnected System

\begin{tabular}{|c|c|c|c|c|c|}
\hline \multicolumn{6}{|c|}{ Power Exchanges - GWh } \\
\hline Year & Internacional & $\begin{array}{l}{ }^{*} \text { SE/MW } \\
\text { South }\end{array}$ & $\begin{array}{c}{ }^{*} \mathrm{SE} / \mathrm{MW} \\
\text { Northeaste }\end{array}$ & \begin{tabular}{|c|} 
North \\
Northeaste
\end{tabular} & $\begin{array}{c}\text { North } \\
{ }^{*} \text { SE/MW }\end{array}$ \\
\hline 2005 & 121,3 & $10.268,0$ & $3.421,0$ & $1.242,4$ & $1.678,0$ \\
\hline 2006 & 502,9 & $29.275,8$ & $2.741,6$ & $1.887,5$ & $4.721,5$ \\
\hline 2007 & $1.842,7$ & $4.963,6$ & $1.930,6$ & $1.299,9$ & $-1.835,4$ \\
\hline 2008 & 683,2 & $5.945,6$ & $5.270,0$ & $14.035,0$ & $-9.262,4$ \\
\hline 2009 & $1.079,3$ & $10.187,4$ & $3.167,6$ & $8.504,2$ & $1.365,4$ \\
\hline 2010 & $1.256,9$ & $-5.649,2$ & $5.334,1$ & $12.054,2$ & $-7.684,5$ \\
\hline
\end{tabular}

Coordinated by the ONS, the proposal for expansion and reinforcement and SIN operation are being made to integrate generation and transmission, to ensure the attendance of all geoelectric regions of the country, with its distinct characteristics of production, consumption and interconnection [14].

The ONS meets its responsibilities by acting on the basis of guidelines and operational measures defined from the development of a set of allotments macrofunctions. These macrofunctions involve analysis and studies performed with the participation of the agents, in accordance with standards and requirements established in the Grid Procedures, which allows the integrated management of generation and transmission resources, which benefits the consumer, agents and society in general [14].

\section{Conclusion}

The electric system of Brazil has as its primary source of a large-scale renewable energy, hydroelectricity. Although it is not a heavily distributed generation system, the study of how this country has been dealing with the variability of supply of each of their enterprises, using the storage capacity and deployment of the country's energy integration can be a source of inspiration for other countries on how to handle the various issues that arise in this integration between macro and micro worlds.

\section{Acknowledgement}

The authors thanks ONS, UFU, PUC-Go and UEG by the support provided.

\section{References}

[1] Atlas de Energia Elétrica do Brasil, $2^{\mathrm{a}}$ Ed. http://www.aneel.gov.br/aplicacoes/atlas/introducao/introducao. htm, september, 2011 
[2] Operador Nacional do Sistema Elétrico - ONS. www.ons.org.br, september, 2011.

[3] Gardos, I; Furst, R.D.; Gomes, P.; Bianco, A. Large Scale Integration of Renewable Sources in the Brazilian Bulk Power System. Rev. Eletro Evolução, n. 63, p. 28-35, 2011.

[4] Musetti, Rodrigo A. Bacias Hidrográficas no Brasil: aspéctos jurídico-ambientais. Rev. CEJ, Brasília, n. 12, pp. 90-94, 2000.

[5] Setti, A.A.; Lima, J.E.F.; Chaves, A. G. M.; Pereira, I. C. Introdução ao Gerenciamento de Recursos Hídricos. Agência Nacional da Água - ANA. Brasília, Brasil, 2000.

[6] Pereira, Dilma S. P.; Garjulli, Rosana; Strauss, Clarisse. The Evolution of the Organization and Implementation of Water Basin Management in Brazil. International Conference of Water Basin Agencies,Madrid,Spain, 2002.

[7] Braga, B. P. F. ANA and Water Management in Brazil: Paying for Results. World Bank Water Week, Whashington, US, 2002.

[8] Sistemas de Informações do Potencial Hidroelétrico Brasileiro - SIPOT. http://www.eletrobras.com/elb/data/Pages/LUMIS21D128D3IT EMID6F8CF9354E0047E084BE9897D5C5DF45PTBRIE.htm, september, 2011.

[9] Braga, Diogo. Processos Autorregressivos Periódicos Gama: Uma Aplicação para Série de Energia Natural Afluente. PESC/COPPE - Universidade Federal do Rio de Janeiro, 2011.

[10] Kowalski, Fábio D.; Pasqual, Dino L.; Toledo Filho, Jorge. A Influência das Usinas Hidroelétricas na Sociedade. III SEGeT

- Simpósio de Excelência em Gestão e Tecnologia, 2006.

[11] Araújo, João L.; Oliveira, Adilson. Diálogos da Energia: reflexões da última década. 7Letras, Rio de Janeiro, 2005.

[12] Zimmermann, Márcio P. et al. Manual de Inventario Hidroelétrico de Bacias Hidrográficas / Ministério de Minas e Energia, CEPEL. E-papers, 2007.

[13] Cachapuz, Paulo B. B. et al. História da Operação do Sistema Interligado Nacional. Centro de Memória da Eletricidade no Brasil - Memória da Eletricidade. Rio de Janeiro, 2003.

[14] Grid Procidures of the National System Operator - ONS. http://extranet.ons.org.br/operacao/prdocme.nsf/principalPRede web?openframeset, september, 2011.

[15] Agência Nacional de Energia Elétrica - ANEEL. http://www.aneel.gov.br, september, 2011. 